University of Nebraska - Lincoln

DigitalCommons@University of Nebraska - Lincoln

Nebraska Game and Parks Commission -- Staff

Research Publications

Nebraska Game and Parks Commission

2016

\title{
Light Goose Conservation Order Effects on Nontarget Waterfowl Behavior and Energy Expenditure
}

\author{
Andrew J. Dinges \\ University of Missouri \\ Elisabeth B. Webb \\ U.S. Geological Survey \\ Mark P. Vrtiska \\ Nebraska Game and Parks Commission, mark.vrtiska@nebraska.gov
}

Follow this and additional works at: https://digitalcommons.unl.edu/nebgamestaff

Dinges, Andrew J.; Webb, Elisabeth B.; and Vrtiska, Mark P., "Light Goose Conservation Order Effects on Nontarget Waterfowl Behavior and Energy Expenditure" (2016). Nebraska Game and Parks Commission -Staff Research Publications. 68.

https://digitalcommons.unl.edu/nebgamestaff/68

This Article is brought to you for free and open access by the Nebraska Game and Parks Commission at DigitalCommons@University of Nebraska - Lincoln. It has been accepted for inclusion in Nebraska Game and Parks Commission -- Staff Research Publications by an authorized administrator of DigitalCommons@University of Nebraska - Lincoln. 


\title{
Light Goose Conservation Order Effects on Nontarget Waterfowl Behavior and Energy Expenditure
}

\author{
ANDREW J. DINGES, ${ }^{\mathbf{1 , 2}}$ Department of Fisheries and Wildife Science, University of Missouri, Columbia, MO 65211, USA \\ ELISABETH B. WEBB, U.S. Geological Survey, Missouri Cooperative Fish and Wildlife Research Unit, Department of Fisheries and Wildlife \\ Sciences, University of Missouri, Columbia, MO 65211, USA \\ MARK P. VRTISKA, Nebraska Game and Parks Commission, 2200 N 33rd Street, Lincoln, NE 68503, USA
}

\begin{abstract}
When the Light Goose Conservation Order (LGCO) was established during 1999 in the Rainwater Basin of Nebraska, USA, LGCO activities were limited to 4 days/week and 16 public wetlands were closed to the LGCO to limit disturbance to nontarget waterfowl during this energetically important time period. However, the effects of LGCO activities on waterfowl behavior and energy expenditure are relatively unknown in this critical waterfowl staging area. To evaluate LGCO effects on target and nontarget species, we paired wetlands open and closed to LGCO and recorded waterfowl behavior and hunter encounters during springs 2011 and 2012. We constructed hourly energy expenditure models based on behavior data collected for mallards (Anas platyrhynchos) and northern pintails (A. acuta). In 2011, dabbling ducks (Anas spp.) spent more time feeding and less time resting in wetlands closed to hunting during early season when the majority of hunting encounters occurred; behaviors did not differ between hunt categories during late season when hunting activities subsided. However, in 2012, dabbling ducks spent more time feeding and less time resting in wetlands open to hunting during early and late seasons. We detected no differences in behaviors of lesser snow geese (Chen caerulescens) or greater white-fronted geese (Anser albifrons) between hunting categories in early season. Mallards had slightly greater energy expenditure on wetlands closed to hunting $(\bar{x}=38.94 \pm 0.31 \mathrm{~kJ} / \mathrm{bird} / \mathrm{hr})$, compared with wetlands open to hunting $(\bar{x}=37.87 \pm 0.32 \mathrm{~kJ} / \mathrm{bird} / \mathrm{hr})$; therefore, greater energy spent by mallards cannot be attributed to hunting disturbance. We also detected no differences in dabbling duck behavior or energy expenditure between days open or closed to hunting in the region. A refuge system of wetlands closed to LGCO activities in the Rainwater Basin may be an important management strategy in providing reduced disturbance for nontarget waterfowl species in some years. Published 2016. This article is a U.S. Government work and is in the public domain in the USA.
\end{abstract}

KEY WORDS behavior, Conservation Order, dabbling ducks, daily energy expenditure, disturbance, light geese, Rainwater Basin, spring migration.

Hunting disturbance can elicit a stronger response in waterfowl than other disturbance activities and has the potential to affect not only birds being pursued, but also associated nontarget species (Belanger and Bedard 1989). Hunting disturbance may affect waterfowl more during spring migration than other times of the year because of the high energy and food requirements associated with migration and subsequent breeding activities (Madsen and Fox 1995, Arzel et al. 2006). Responses to hunting disturbance include no reaction, increased alertness and walking/ swimming away from the source of disturbance, and escape

Received: 30 September 2015; Accepted: 29 May 2016

Published: 2 November 2016

${ }^{1}$ E-mail: adinges8@gmail.com

${ }^{2}$ Present address: 312 12th Avenue NW, Mandan, ND 58554, USA flights (Madsen and Fox 1995). Many of these responses to hunting disturbance generally reduce foraging time for waterfowl using disturbed areas (Madsen and Fox 1995). The time it takes birds to resume the activity they were performing varies among species. The ability to compensate for energetic losses incurred by disturbance generally depends on a species' preferred forage (Belanger and Bedard 1989, Madsen and Fox 1995). Species that require longer feeding times to fulfill daily energy demands, such as gadwall (Anas strepera) feeding exclusively on wetland plants (Paulus 1982), are generally less able to energetically compensate for disturbance events, compared with birds that forage on highenergy waste grains (Belanger and Bedard 1989, Madsen and Fox 1995).

Populations of light geese (lesser snow geese [Chen caerulescens] and Ross's geese [C. rossi]) wintering in the midcontinent United States have grown substantially since 
the 1970s and may currently exceed 15 million birds in the autumn (Alisauskas et al. 2011). Destruction of some arctic breeding habitats has resulted from significant increases in midcontinent light goose populations (Abraham and Jefferies 1997, Jefferies and Rockwell 2002). The U.S. Fish and Wildlife Service (USFWS) implemented the Light Goose Conservation Order (LGCO) in 1999 in an effort to reduce midcontinent populations of light geese (Abraham et al. 2005, USFWS 2007). No legal nonsubsistence waterfowl hunting has taken place after 10 March since the signing of the Migratory Bird Treaty Act in 1918 (USFWS 2007); however, the LGCO allows the legal harvest of light geese after this date while all other waterfowl seasons are closed. Special measures such as unplugged shotguns, use of electronic calls, and shooting hours extended to $30 \mathrm{~min}$ after sunset are also allowed. The LGCO is not a hunting season per se, but current methodologies used to harvest light geese are similar to those used in the regular hunting season and carried out by migratory bird hunters; thus, we use the terms LGCO activities and hunting interchangeably.

Activities during the LGCO are a potential source of disturbance for nontarget waterfowl species during spring migration in the Rainwater Basin (RWB) of Nebraska, USA, and may influence bird behavior (Webb et al. 2011). The LGCO was implemented with restrictions based on concern from managers that hunting disturbance may negatively affect behavior of nontarget waterfowl species using the RWB. Since 2004 and during our study, LGCO regulations in the RWB limited hunting to 4 days/week (Saturday, Sunday, Wednesday, and Thursday) and 16 specific public wetlands (state or federally owned and managed) were entirely closed to hunting. After the third week of March, hunting was allowed 7 days/week and the LGCO season closed in the RWB during the second week of April. Regulations were established with the concurrent goal of maximizing light goose harvest and minimizing potential effects of hunting disturbance on nontarget species; however, the effect these regulations have on waterfowl behavior in the RWB during the LGCO are still relatively unknown (Vrtiska and Sullivan 2009). In addition, while numerous studies have evaluated effects of hunting disturbance on waterfowl species during seasons when those species were open to harvest (Belanger and Bedard 1989, Madsen and Fox 1995, Bechet et al. 2004), less is known about how nontarget species, specifically dabbling ducks, respond to hunting disturbance during time periods when they are not legally pursued (Pearse et al. 2012).

In an effort to quantify behavioral differences of waterfowl between wetlands open and closed to LGCO activities in the RWB, Webb et al. (2011) observed a smaller proportion of dabbling ducks (Anas spp.) feeding in wetlands open to hunting compared with wetlands closed to hunting or in wetlands open to hunting after the end of the LGCO. Webb et al. (2011) concluded behaviors of nontarget species, specifically dabbling ducks, were more affected by hunting disturbance than target species, but did not record data on hunting participation for wetlands open to hunting.
Therefore, it was possible wetlands classified as open to hunting did not experience actual hunting pressure. Whether through increased flight time or reduced foraging time, hunting disturbance during the LGCO in the RWB has the potential to influence behaviors of nontarget species, which could limit lipid acquisition and ultimately affect subsequent reproductive output and breeding success of waterfowl (Madsen and Fox 1995, Mainguy et al. 2002, Bechet et al. 2004, Devries et al. 2008, Webb et al. 2011). Therefore, our objectives were to quantify hunter participation during the LGCO and assess effects of hunting disturbance during the LGCO on behavior and energy expenditure of nontarget waterfowl in the RWB of Nebraska. We surveyed wetlands for the presence of LGCO participants and conducted behavioral observations on waterfowl during spring (midFeb-late Mar) migrations 2011 and 2012 to evaluate the effects of LGCO activities.

\section{STUDY AREA}

The RWB region occupied a $16,000-\mathrm{km}^{2}$ area that covered 21 counties in south-central Nebraska (Bishop and Vrtiska 2008) and was recognized as an important waterfowl habitat area in North America (USFWS and Canadian Wildlife Service 1986). The RWB region has variable precipitation and most wetlands are not connected to groundwater inflow, resulting in high annual variation in inundated wetland availability (Brennan et al. 2005, LaGrange 2005, Vrtiska and Sullivan 2009). Wetland hydrology was often supplemented by pumping groundwater directly from the Ogallala Aquifer on several publicly owned wetland basins during years with low precipitation (Smith et al. 1989, Smith and Higgins 1990). Classification of most wetlands in the region fell into 1 of 3 palustrine emergent wetland hydrologic regimes (Gersib et al. 1989): temporarily, seasonally, or semipermanently inundated (Cowardin et al. 1979).

Despite the loss of $>90 \%$ of wetland basins and degradation of remaining RWB wetlands since European settlement, the area still serves as a major spring staging area for waterfowl in North America (Gersib et al. 1989). Approximately 9.8 million waterfowl continue to use the RWB region each year during spring migration (Bishop and Vrtiska 2008); including $50 \%$ of the midcontinent population of mallards (A. platyrhynchos) and 30\% of the continental population of northern pintails ( $A$. acuta; hereafter, pintails; Gersib et al. 1989, LaGrange 2005). Also, $>1.5$ million light geese are now estimated to use the RWB during spring migration, a substantial increase since the late 1980s, when only a few thousand light geese were observed annually (Gersib et al. 1989, Bishop and Vrtiska 2008, Vrtiska and Sullivan 2009).

\section{METHODS}

\section{Wetland Selection}

To account for annual variation in precipitation and inundated wetland availability (Bishop and Vrtiska 2008), we selected study wetlands on an annual basis, assessing potential sites for inundation that made them available to 
waterfowl, with ground surveys in late January and early February 2011 and 2012. We paired public wetlands closed to LGCO activities with either 1 or 2 public wetlands open to LGCO activities (hunting category) based on similarities in wetland area, vegetation cover, and geographic location (i.e., western or eastern RWB wetlands). Wetlands open to hunting were more numerous and, in some cases, we grouped 2 wetlands open to hunting with 1 wetland closed to hunting to take advantage of having an additional observer in some instances and potentially increase the probability of detecting hunting parties. We visually estimated wetland area as a percentage of the hydric footprint containing water and determined vegetation cover types using methods described by Stewart and Kantrud (1971). We used 38 public wetlands (23 open to hunting and 15 closed to hunting) as study sites over the 2 years of our study (Fig. 1).

\section{Focal Behavior and Statistical Analyses}

We quantified waterfowl behavior on study wetlands open and closed to hunting by simultaneously conducting focal behavior observations (Altman 1974) with multiple observers at each wetland pair or group during springs 2011 and 2012 (mid-Feb-late Mar). If 2 wetlands open to hunting were grouped with 1 wetland closed to hunting, we alternated visits between wetlands open to hunting for that group if a third observer was not available. We made focal observations for approximately $1 \mathrm{hr}$ at each study wetland, during which time we recorded any hunting parties. To quantify hunting participation on wetlands open to hunting during the LGCO, we recorded number of hunting parties ( $\geq 1$ people) present and actively pursuing light geese during each wetland observation. We also opportunistically queried potential hunters on roads, parking lots, etc. to gather as much information as possible about their hunting behavior for that day, including times and locations of their hunting activities.

During each wetland observation, we estimated the percent of the wetland containing water (\% full) by visually comparing current water levels with aerial photographs and the extent of the wetland plant boundary (Webb et al. 2010). Within the inundated wetland area, we also estimated the percent cover of emergent vegetation cover for each observation period. After completion of each wetland observation, we moved to observe another wetland pair; we typically completed 4-5 wetland pair observations/day and surveyed each wetland pair approximately 3-4 times/week. We divided the diurnal time period into 4 intervals; dawn (30 min before sunrise-0900 hr), morning (0900-1230 hr),

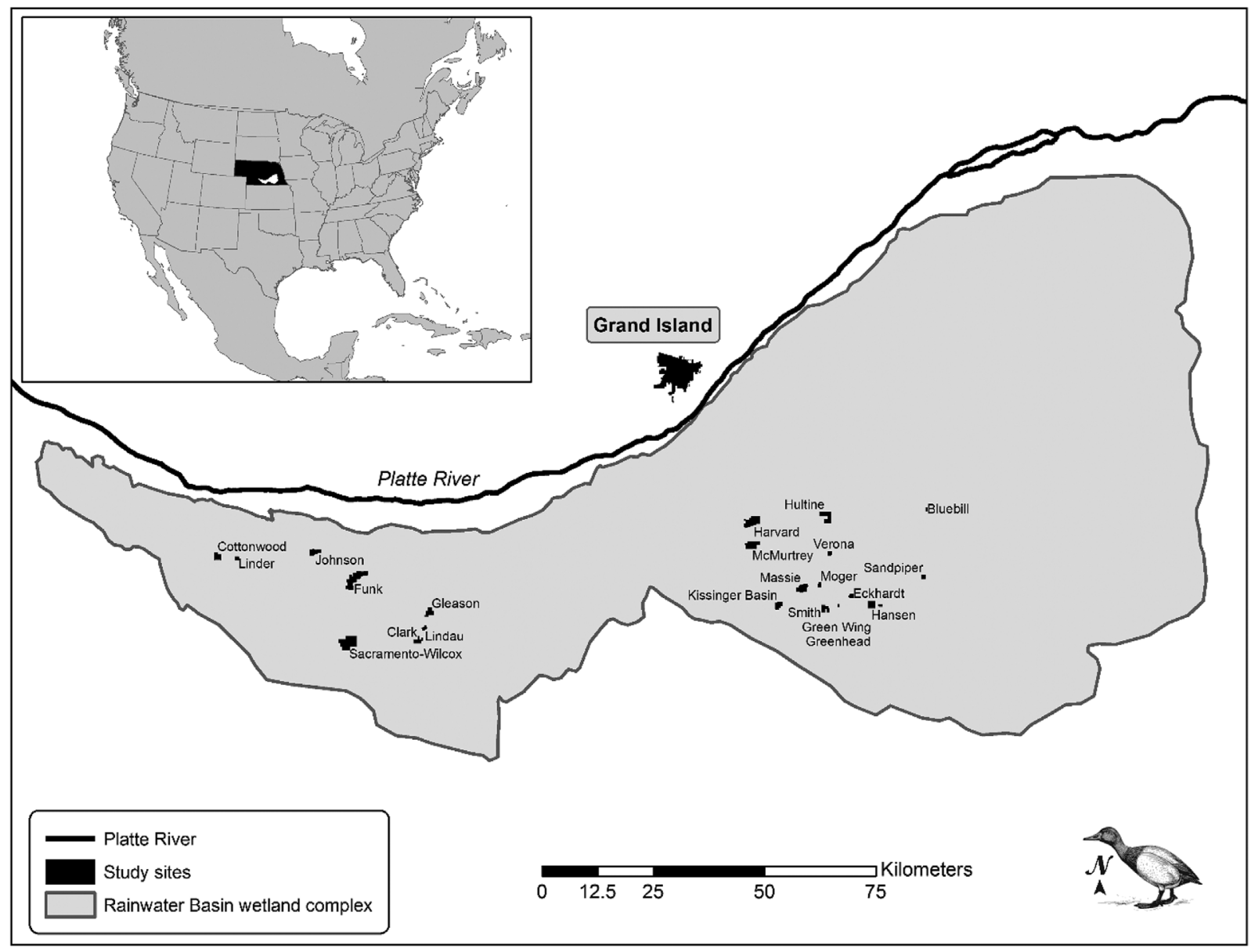

Figure 1. Public wetlands ( $n=38 ; 15$ closed and 23 open to hunting) used as study sites to conduct waterfowl behavior observations and document hunting participants during the Light Goose Conservation Order in the Rainwater Basin of Nebraska, USA, during springs 2011 and 2012. 
afternoon (1230-1600 hr), and evening (1600 hr-30 min after sunset) similar to Webb et al. (2011). Although we were not directly interested in behavior differences among time periods, we attempted to collect an equal number of focal observations for each species and each study wetland within these time periods to account for potential differences in diurnal behaviors (Webb et al. 2011).

We conducted focal observations on lesser snow geese, greater white-fronted geese (Anser albifrons; hereafter, white-fronts), pintails, and mallards. Observations of pintails and mallards were combined for behavior analyses (hereafter, dabbling ducks). We attempted to conduct an equal number of observations between adult and juvenile geese and between male and female dabbling ducks at each study wetland and for each time period. We observed birds with spotting scopes from a vantage point in either a truck or a ground blind that permitted an unobstructed view of the study wetland and attempted to limit disturbance to waterfowl. We selected an individual bird of each species within the viewing area after randomly moving the spotting scope. We recorded behavior every $10 \mathrm{sec}$ for a maximum of $5 \mathrm{~min}$. We classified behaviors into 1 of 6 categories (following Jorde et al. 1984, Davis and Smith 1998): resting, feeding, locomotion, maintenance, alert, and social (i.e., courtship and aggression).

Prior to analysis, we removed any focal observations with behaviors recorded for $<50 \%$ of the designated 5 -min sampling period. We converted frequency of each behavior to a proportion of the overall observation for each focal bird. We also reclassified 3 study wetlands that were open to hunting in 2012 as closed for data analysis because we observed no hunting encounters on them. We determined the variable hunt day for each focal observation based on the designation of that particular day being open or closed to LGCO activities. We defined season (early and late) based on the temporal decline of light geese observed on study wetlands. We classified early season as those weeks prior to the date when $>95 \%$ of all light geese observed on study wetlands each year (based on our abundance counts) left the RWB region, while we classified late season as all weeks after that date (Webb et al. 2011, Dinges et al. 2015). Consequently, hunting encounters recorded on study wetlands also declined sharply during late season. We also speculated that differences in waterfowl densities recorded on study wetlands during early and late seasons could influence waterfowl behaviors (Dinges et al. 2015). We classified all surveys conducted prior to 14 March 2011 and 12 March 2012 as early season.

We used analysis of variance (ANOVA) to test for differences in wetland area and percent vegetation cover between wetlands open and closed to the LGCO. We used multivariate analysis of variance (MANOVA) to test for differences in overall dabbling duck behaviors (Davis and Smith 1998, Webb et al. 2011) because multivariate analysis accounts for correlation among multiple dependent variables and is generally considered more powerful than a series of separate ANOVAs (Zar 1999). Additionally, the $F$-test in MANOVA is robust to nonnormality, if the nonnormality is caused by skewed data distribution, rather than outliers (Finch 2005). We tested for effects of year, season, hunt category, hunt day, and all possible interactions on behaviors of mallards and pintails combined (PROC GLM; SAS Institute Inc. 2010). We included year in our model evaluating dabbling duck behavior because wetland conditions as well as timing and length of spring migration can vary substantially from year to year in the RWB, which could potentially affect behavior (Webb et al. 2010, Dinges et al. 2015). We also evaluated effects of species, season, and hunt category and all possible interactions on goose behaviors (PROC GLM; SAS Institute Inc. 2010). We excluded year in the analysis for geese because of low sample size within each year.

For behavior observations recorded on wetlands open to hunting, we also tested for effects of observed hunting frequency on behavior of dabbling ducks. We used MANOVA to test for differences in overall behavior based on weekly and cumulative hunting encounter frequencies recorded on study wetlands (PROC GLM; SAS Inst.). For weekly hunting frequency, we tested for differences in dabbling duck behavior observations collected among 3 frequency categories: 0,1 , and $\geq 2$ weekly hunting encounters. We classified cumulative hunting encounters at sites open to hunting into 4 categories: $0,1,2-3$, and $\geq 4$ total hunting encounters. We based cumulative hunting categories primarily on the frequency distribution of cumulative hunting encounters, resulting in a relatively equal sample size among categories. We restricted our analyses of dabbling duck behavior based on weekly and cumulative hunting encounter frequencies to early season when $>90 \%$ of hunting encounters occurred on study wetlands. We used Wilks' lambda $(\lambda)$ as the test criterion for all MANOVA models. Following a significant MANOVA, we used separate ANOVAs to examine differences in individual behaviors among independent variables. We used Tukey's post hoc test following significant ANOVAs for individual behaviors to determine differences among independent categories >2 (PROC GLM; SAS Institute Inc. 2010).

\section{Hourly Energy Expenditure and Statistical Analyses}

We aggregated behavior data for mallards and pintails into the following categories: resting, feeding, locomotion, maintenance (maintenance, alert), and social (courtship, aggression) to facilitate development of energy expenditure models (McKinney and McWilliams 2005). We then used focal behavioral observations to estimate diurnal hourly energy expenditure (HEE) for mallards and pintails using methods similar to Albright (1983) and Jones et al. (2014), with the following equation:

$$
H E E=\sum_{i=1}^{n}\left\{\left[\left(R M R \times a_{i}\right)+C T\right] \times T_{i}\right\}
$$

where $R M R=$ resting metabolic rate $(\mathrm{kJ} / \mathrm{bird} / \mathrm{hr}), a_{i}=$ activity-specific factorial increase in $R M R$ for the $i$ th behavioral activity, $C T=$ cost of thermoregulation at a specified temperature $(\mathrm{kJ} / \mathrm{bird} / \mathrm{hr}), T_{i}=$ proportion of time 
engaged in the $i$ th behavioral activity; all values were summed across behaviors (i) to derive an estimate of total energy expenditure $(\mathrm{kJ} / \mathrm{bird} / \mathrm{hr})$ for each individual observation. We then multiplied each 5-min estimate of energy expenditure by 12 to calculate HEE. We did not use behavioral observations for snow geese and white-fronted geese to construct $H E E$ models because geese spent much of the diurnal period in agriculture fields (Bishop and Vrtiska 2008, Pearse et al. 2013), and we believed behavior observations collected on only wetlands would not accurately represent diurnal energy expenditure for this group.

We estimated $R M R$ for males and females of both species using an allometric equation derived by Miller and Eadie (2006):

$$
R M R=a M a s s^{b}
$$

where $a=$ a mass proportionality coefficient, Mass=body mass $(\mathrm{kg})$, and $b=$ slope of the regression line on a log scale. We used the predicted $a$ and $b$ constants based on the allometric relationships reported for the group "dabbling ducks" ( $a=457, b=0.77$; Miller and Eadie 2006). We used body masses of midwinter mallards $(\mathrm{F}=1.096 \mathrm{~kg}$, $\mathrm{M}=1.246 \mathrm{~kg})$ and pintails $(\mathrm{F}=0.887 \mathrm{~kg}, \mathrm{M}=1.006 \mathrm{~kg})$ previously reported by Drilling et al. (2002) and Clark et al. (2014). We used values derived by Wooley (1976) for activity-specific factorial increases in $R M R\left(a_{i}\right)$ as follows: 1.2 for resting, 1.7 for feeding, 2.2 for locomotion, 2.4 for social activities, and 2.1 for maintenance.

We calculated the cost of thermoregulation similar to Jones et al. (2014) using the following equation:

$$
C T=m_{c} \times \Delta T_{L C T-T w c}
$$

where $m_{c}$ is the slope of increasing metabolic energy below the lowest critical temperature $(L C T)$, which we derived from Wooley and Owen (1977), and $\Delta T_{L C T-T w c}$ is the difference between wind chill temperature from the lowest critical temperature. If wind chill temperature was above the $L C T$ we assumed that the cost of thermoregulation was zero (Wooley and Owen 1977). We estimated the $L C T$ for each species and sex using the empirical relationship derived by Kendeigh et al. (1977) for nonpasserines:

$$
L C T=47.2 M^{-0.18}
$$

where $L C T$ is in ${ }^{\circ} \mathrm{C}$ and $M$ is body mass in grams. Estimated $L C T$ s were similar between species and sexes, ranging from a high of $13.9^{\circ} \mathrm{C}$ for female pintails to a low of $13.08^{\circ} \mathrm{C}$ for male mallards. Therefore, we used a constant $L C T$ of $13.0^{\circ} \mathrm{C}$ for all observations, regardless of species or sex. We used ANOVA with the independent variables of sex, season, hunting category, hunt day, and all possible interactions to test for effects on $H E E$ for both mallards and pintails (PROC GLM; SAS Institute Inc. 2010). We performed all statistical analyses with SAS software version 9.3 (SAS Institute Inc. 2010). We controlled Type I error rate at $\alpha=0.05$, and report all means \pm standard error.

\section{RESULTS}

We observed 70 hunting parties on study wetlands during 2011 and 2012, 38 (54\%) in 2011, and 32 (46\%) in 2012. Hunting parties recorded on study wetlands were distributed evenly between weekdays open to hunting and weekends open to hunting (35 encounters each). Total hunting encounters recorded were also distributed relatively equally among the 4 diurnal time periods; $32 \%$ at dawn, $31 \%$ in morning, $27 \%$ in afternoon, and $10 \%$ in evening. Of the hunting encounters observed on study wetlands, $81 \%$ occurred in the eastern RWB, while only $19 \%$ occurred in the western RWB. We recorded $91 \%$ of study wetland hunting encounters during the early season. Every study wetland classified as open to hunting was hunted at least once during early season in both 2011 and 2012. Study wetlands classified as open $(\bar{x}=20.8 \pm 2.6 \mathrm{ha})$ to hunting did not differ in inundated area compared with wetlands closed $(\bar{x}=18.6 \pm 2.7 \mathrm{ha})$ to hunting $\left(F_{1,36}=0.30, P=0.59\right)$. We also detected no differences in percent vegetation cover between open $(\bar{x}=22.4 \% \pm 4.4)$ and closed $(\bar{x}=31.0 \%$ \pm 5.0 ) wetlands $\left(F_{1,36}=1.62, P=0.21\right)$.

\section{Focal Behavior}

We recorded 2,947 focal observations in springs 2011 and 2012 (1,253 mallards, 1,307 pintails, 210 snow geese, and 177 white-fronts). We detected a 3-way interaction among year, season, and hunting category in our initial analysis of dabbling duck behaviors (Wilks' $\lambda=0.99, P=0.002$ ). Analyzing behaviors separately by year, we detected 2-way interactions between hunting category and season for both 2011 (Wilks' $\lambda=0.98, P=0.03$ ), and 2012 (Wilks' $\lambda=0.99$, $P=0.03$ ). Consequently, we tested for the main effects of hunting category by season and year in our final analysis of dabbling duck behaviors.

In 2011, overall dabbling duck behaviors differed between hunting categories during early season (Wilks' $\lambda=0.95, P<0.001)$, but not during late season when hunting disturbance subsided (Wilks' $\lambda=0.99, P=0.82$ ). Dabbling ducks spent more time feeding in wetlands closed to hunting $(\bar{x}=21 \% \pm 2)$, compared with wetlands open to hunting $(\bar{x}=11 \% \pm 2)$ during early season 2011 $\left(F_{1,415}=11.53, P \leq 0.001\right.$; Fig. 2$)$. Dabbling ducks also spent less time resting in wetlands closed to hunting $(\bar{x}=29 \% \pm 3)$, compared with wetlands open to hunting $(\bar{x}=46 \% \pm 2)$ during early season $2011\left(F_{1,415}=20.20\right.$, $P \leq 0.001$; Fig. 2). We found no effects of hunt day or hunt day $\times$ hunt category interactions during early or late season for dabbling duck behaviors in 2011 (all Wilks' $\lambda \geq 0.98$, $P \geq 0.12$ ).

In 2012, dabbling duck behaviors differed between hunting categories in both early (Wilks' $\lambda=0.95, P<0.001$ ) and late seasons (Wilks' $\lambda=0.95, P<0.001$ ). During early season, dabbling ducks spent more time feeding in wetlands open to hunting $(\bar{x}=37 \% \pm 2)$, compared with wetlands closed to hunting ( $\bar{x}=26 \% \pm 1 ; F_{1,1085}=22.55, P<0.001$; Fig. 2 ). Dabbling ducks also spent less time resting in wetlands open to hunting $(\bar{x}=29 \% \pm 2)$ in comparison to wetlands closed to hunting $(\bar{x}=35 \% \pm 3)$ during early season 2012 
$\left(F_{1,1085}=5.03, P=0.03 ;\right.$ Fig. 2). In late season 2012, dabbling ducks still spent more time feeding in wetlands open to hunting $(\bar{x}=33 \% \pm 3)$, compared with wetlands closed to hunting $\left(\bar{x}=26 \% \pm 2 ; F_{1,665}=4.23, P=0.04\right.$; Fig. 2). Dabbling ducks also spent less time in maintenance activities on wetlands open to hunting during late season in $2012(\bar{x}=12 \% \pm 1)$, compared with wetlands closed to hunting $\left(\bar{x}=21 \% \pm 1 ; F_{1,665}=18.06, P<0.001\right.$; Fig. 2$)$. We found no effects of hunt day or hunt day $\times$ hunt category interactions in early or late season for dabbling duck behaviors in 2012 (all Wilks' $\lambda \geq 0.99, P \geq 0.22$ ).

There was no difference in overall dabbling duck behavior based on weekly hunting frequency during early season (Wilks' $\lambda=0.98, \quad P=0.12$ ). However, observations of dabbling duck behaviors differed based on cumulative hunting frequency during early season (Wilks' $\lambda=0.97$, $P=0.05)$. Resting behavior was different among cumulative hunting-frequency categories $\left(F_{3,660}=3.50, \quad P=0.02\right)$. Dabbling ducks in the 0 and 1 cumulative hunting category spent less time resting $(\bar{x}=30 \% \pm 3$ and $\bar{x}=31 \% \pm 2$, respectively), compared with birds in the highest huntingfrequency category $(\bar{x}=42 \% \pm 3$; Fig. 3). Feeding behavior also differed among cumulative hunting-frequency categories $\left(F_{3,660}=4.99, P=0.002\right)$. Dabbling ducks in the cumulative hunting-frequency category 1 spent more time feeding $(\bar{x}=36 \% \pm 3)$, compared with birds in the highest hunting-frequency category $(\bar{x}=21 \% \pm 3$; Fig. 3$)$.

There was a 3-way interaction between species, season, and hunting category in our initial analysis of goose behavior (Wilks' $\lambda=0.95, P=0.01$ ). Evaluating behaviors separately by species, we detected 2 -way interactions between hunting category and season for both snow geese (Wilks' $\lambda=0.93$, $P=0.04$ ) and white-fronts (Wilks' $\lambda=0.91, P=0.01$ ). Overall behaviors of white-fronts did not differ between hunting categories in early season (Wilks' $\lambda=0.93, P=0.16$ ) or late season (Wilks' $\lambda=0.82, P=0.07$; Fig. 4). Snow goose behaviors did not differ between hunting categories during early season (Wilks' $\lambda=0.97, P=0.38$ ), but overall behavior differed during late season (Wilks' $\lambda=0.77, P=0.02$ ). Snow geese spent more time in locomotion on wetlands open to hunting $(\bar{x}=26 \% \pm 7 \%)$ during late season compared with wetlands closed to hunting $\left(\bar{x}=6 \% \pm 1 \% ; F_{1,54}=14.73\right.$, $P=0.02$; Fig. 4).

\section{Hourly Energy Expenditure}

We detected no interactions among independent variables in our initial analyses of diurnal $H E E$ for mallards (all $F \leq 2.41$, $P \geq 0.12$ ) or pintails (all $F \leq 2.76, P \geq 0.10$ ). There was no difference $\left(F_{1,1306}=0.24, P=0.63\right)$ in $H E E$ between hunting categories detected for pintails (Fig. 5). However, $H E E$ for mallards was greater on wetlands closed to hunting $(\bar{x}=38.94$ $\pm 0.31 \mathrm{~kJ} / \mathrm{bird} / \mathrm{hr}$ ), compared with wetlands open to hunting $\left(\bar{x}=37.87 \pm 0.32 \mathrm{~kJ} /\right.$ bird $/ \mathrm{hr} ; F_{1,1252}=6.24, P=0.01 ;$ Fig. 5$)$. Hourly energy expenditure was also greater in early season for both mallards $(\bar{x}=40.31 \pm 0.29 \mathrm{~kJ} / \mathrm{bird} / \mathrm{hr})$ and pintails $(\bar{x}=34.91 \pm 0.24 \mathrm{~kJ} / \mathrm{bird} / \mathrm{hr})$, compared with late season (mallard $\bar{x}=35.97 \pm 0.33 \mathrm{~kJ} / \mathrm{bird} / \mathrm{hr}$, and pintail $\bar{x}=31.85$ $\pm 0.30 \mathrm{~kJ} / \mathrm{bird} / \mathrm{hr}$; both $F \geq 70.58, P<0.001)$. Hourly energy expenditure was greater for both male mallards $(\bar{x}=40.86$ $\pm 0.32 \mathrm{~kJ} / \mathrm{bird} / \mathrm{hr})$ and pintails $(\bar{x}=35.97 \pm 0.28 \mathrm{~kJ} / \mathrm{bird} / \mathrm{hr})$, compared with females (mallard $\bar{x}=36.15 \pm 0.29 \mathrm{~kJ} / \mathrm{bird} / \mathrm{hr}$, and pintail $\bar{x}=31.51 \pm 0.23 \mathrm{~kJ} / \mathrm{bird} / \mathrm{hr}$; both $F \geq 92.87$, $P<0.001$; Fig. 5). Hunt day did not have an effect on mallard $\left(F_{1,1252}=1.74, P=0.19\right)$, or pintail $\left(F_{1,1306}=1.65, P=0.20\right)$ HEE (Fig. 5).

\section{DISCUSSION}

Our results provide some support for effects of the LGCO on behavior of nontarget species. We attribute reduced foraging time by dabbling ducks on wetlands open to hunting

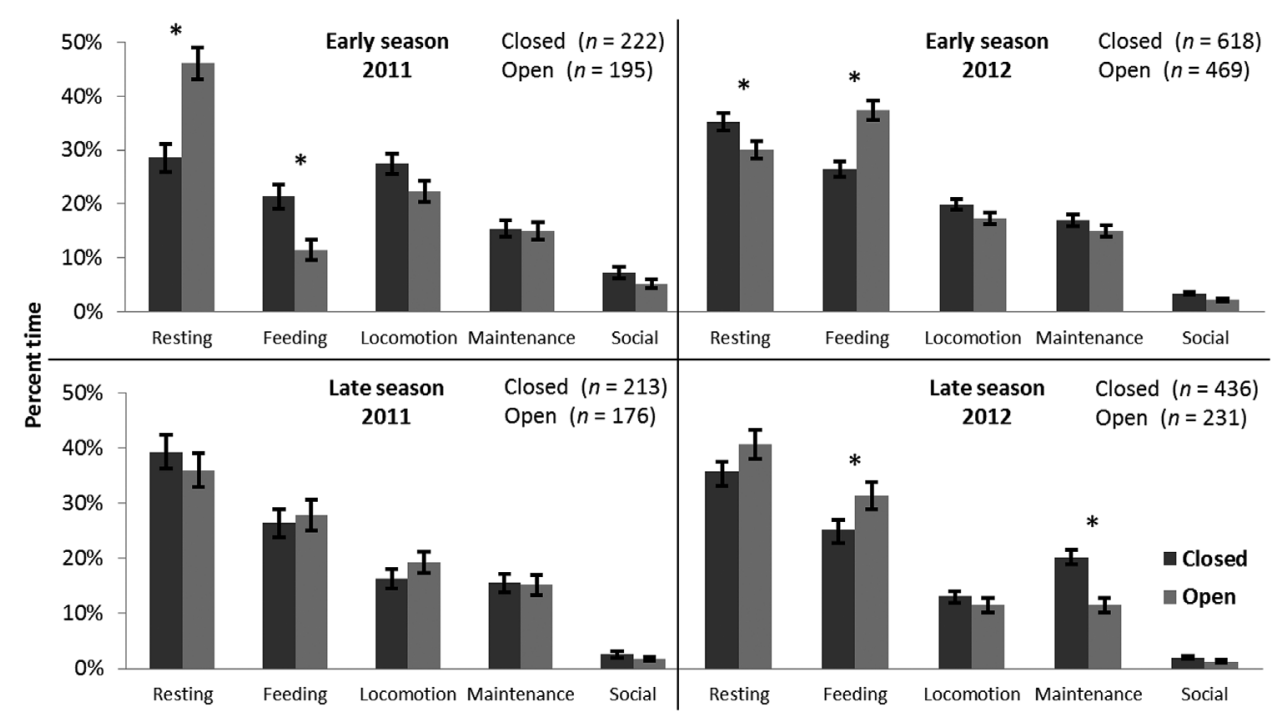

Figure 2. Percent time $(\bar{x} \pm \mathrm{SE})$ spent by mallards and northern pintails in behaviors during early and late seasons on wetlands open and closed to hunting during the Light Goose Conservation Order in the Rainwater Basin (RWB) of Nebraska, USA, during 2011 and 2012 . We classified early season as those weeks prior to the date when $>95 \%$ of all light geese observed on study wetlands each year had left the RWB region, late season was considered all weeks after that date. The asterisk symbol indicates statistical differences $(P \leq 0.05)$ between categories. 


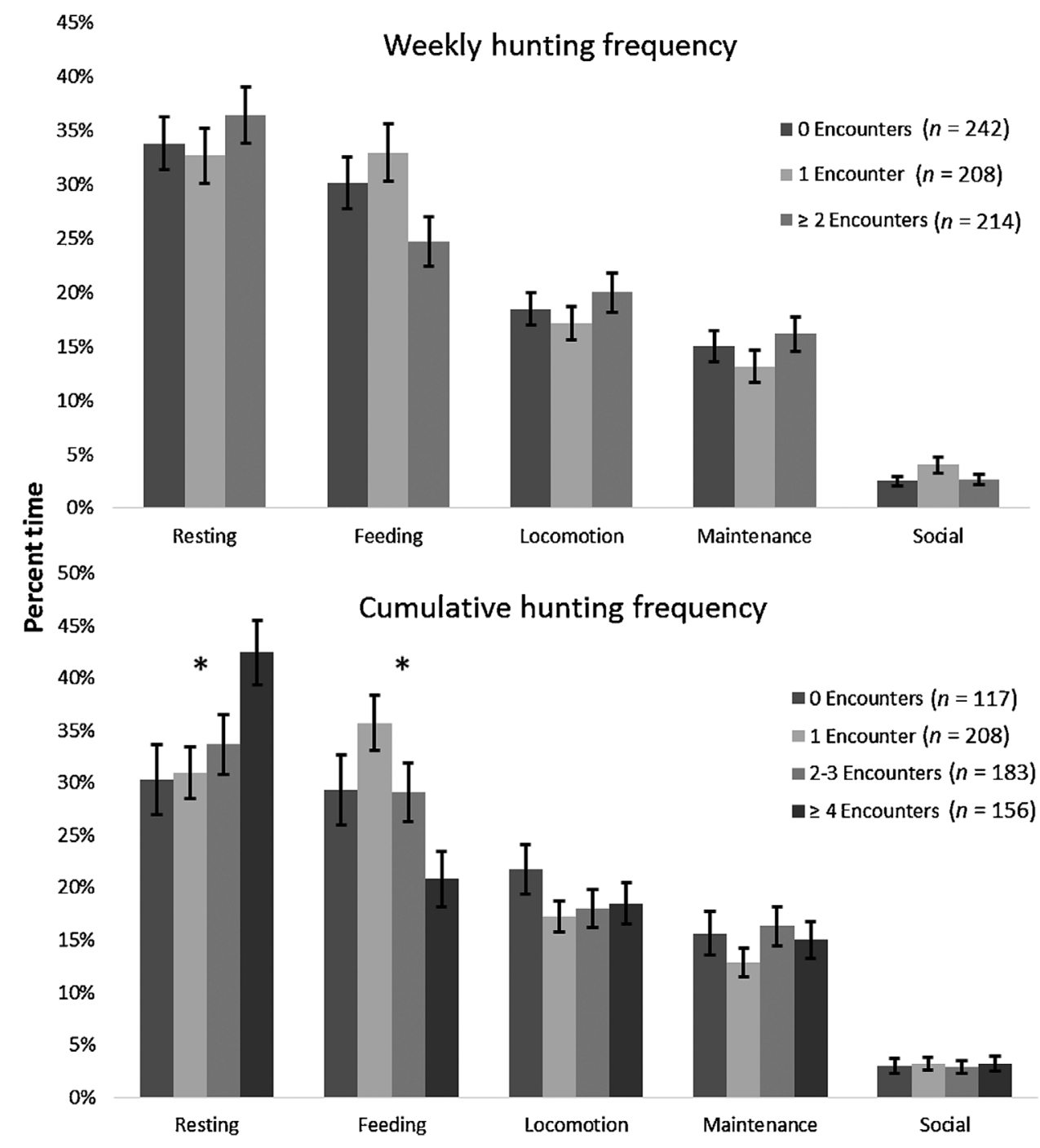

Figure 3. Dabbling duck (Anas spp.) behaviors on wetlands open to hunting in early season based on weekly and cumulative hunting-encounter frequency during the Light Goose Conservation Order in the Rainwater Basin (RWB) of Nebraska, USA, during springs 2011 and 2012 . We classified early season as those weeks prior to the date when $>95 \%$ of all light geese observed on study wetlands each year had left the RWB region. The asterisk symbol indicates statistical differences $(P \leq 0.05)$ between categories.

in early season 2011 to disturbance caused by LGCO activities. Support for this conclusion is based on the fact that after hunting encounters declined by $>90 \%$ on study wetlands in late season, we observed no difference in overall dabbling duck behaviors between wetlands in different hunting categories. Our late-season behavior results also indicate that potential habitat differences among study sites were not likely responsible for observed differences in dabbling duck behaviors between hunting categories in early season 2011. Results of our cumulative hunting-frequency analysis on wetlands open to hunting during early season also has some support for the same trend of dabbling ducks resting more and feeding less as hunting disturbance increases. Webb et al. (2011) also observed a smaller proportion of dabbling ducks feeding in wetlands open to LGCO hunting, compared with wetlands closed to hunting in the RWB.

However, dabbling ducks spent more time foraging in wetlands open to hunting during both early and late seasons in 2012. Annual differences in foraging time between wetlands open and closed to hunting may be attributed to differences in migration chronology. Migration occurred over a shorter period in 2012 compared with 2011 (Dinges et al. 2015), and perhaps individual birds spent less time in the RWB area during 2012. If residency time was shorter, LGCO activities over this more limited time period may have had less potential to influence dabbling duck behavior. Also, although we did not quantify habitat quality or availability, potential differences in habitat quality or availability may have influenced our results for dabbling duck behavior during 2012. In addition, similar to other waterfowl behavior studies, we recorded resting (sleeping and loafing) and alert behaviors (high scan vigilance) separately (Paulus 1988). Given the pattern we observed in 2011 and in our cumulative hunting results of dabbling ducks spending more time resting in wetlands as the result of increases in hunting disturbance, we suspect birds were spending some of this resting time in a low-scan vigilant behavior. However, 
we did not distinguish a low-scan vigilant behavior from other resting behaviors, which may often be difficult to detect (Rümmler et al. 2016). Distinguishing low-scan vigilant behaviors from other resting behaviors may have provided clearer interpretation of results, and we encourage researchers to try to develop methods to distinguish this behavior in future disturbance research if possible.

We recorded behavior data on species that have been known to supplement their diets with waste corn while staging in the RWB (Jorde et al. 1984, Krapu et al. 1995, Pearse et al. 2011). We frequently observed mallards and pintails feeding in agriculture fields near study sites, particularly during early season when temperatures were often at or below freezing temperature (Dinges 2013). Pearse et al. (2011) reported diets of pintails collected on RWB wetlands included $54 \%$ corn. Thus, if mallards and pintails supplement their diets with high-energy waste corn, they may need to forage less in wetlands while staging in the RWB and perhaps more readily compensate for lost foraging time due to hunting disturbance (Baldassarre et al. 1983, Baldassarre and Bolen 1984). Nonetheless, even if highenergy corn is substituted in dabbling ducks diets while staging in the RWB, a diet of exclusively corn is nutritionally inadequate, especially for females preparing for later reproductive efforts (Loesch and Kaminski 1989). In addition, mallards and pintails increase consumption of macroinvertebrates prior to spring migration and likely continue this foraging strategy during spring staging as well (Heitmeyer 1985, Miller 1987, Tidwell et al. 2013). Therefore, providing dabbling ducks with foraging opportunities in RWB wetlands free from hunting disturbance is likely an important component to meeting the nutritional requirements of dabbling ducks during migration (Arzel et al. 2006, Webb et al. 2011, Tidwell et al. 2013).

The potential long-term population effects of reduced foraging time caused by LGCO activities on dabbling ducks are challenging to quantify because they are generally considered income breeders (Drent et al. 2006, 2007). However, there appears to be some evidence of a link between body condition and nutrient reserves at staging sites and subsequent breeding success (Anteau and Afton 2004, Devries et al. 2008). Although we documented reduced foraging time in relation to hunting disturbance for dabbling ducks during 1 year of our study, we did not assess whether reduced foraging activity influenced body condition of dabbling ducks that used wetlands open to hunting that year. We also did not quantify food availability, estimates of foraging efficiency (Reinecke et al. 1989), or food depletion rates (Greer et al. 2009), which ultimately influence energy intake for foraging waterfowl (Bechet et al. 2004). Estimating dabbling duck energy intake based on time spent foraging in RWB wetlands with often diverse plant and invertebrate communities would be challenging (Gordon et al. 1990, Pearse et al. 2011, Tidwell et al. 2013). However, further investigation into body condition and lipid reserves of dabbling ducks, specifically collected on wetlands open and closed to hunting during the LGCO may provide further insight into potential carry-over effects of reduced foraging time as the result of spring hunting on RWB wetlands.

Behaviors of both white-fronts and snow geese did not differ between wetlands open and closed to hunting in early season when the majority of hunting encounters occurred on study sites. Webb et al. (2011) also concluded behaviors of nontarget species, specifically dabbling ducks, were more

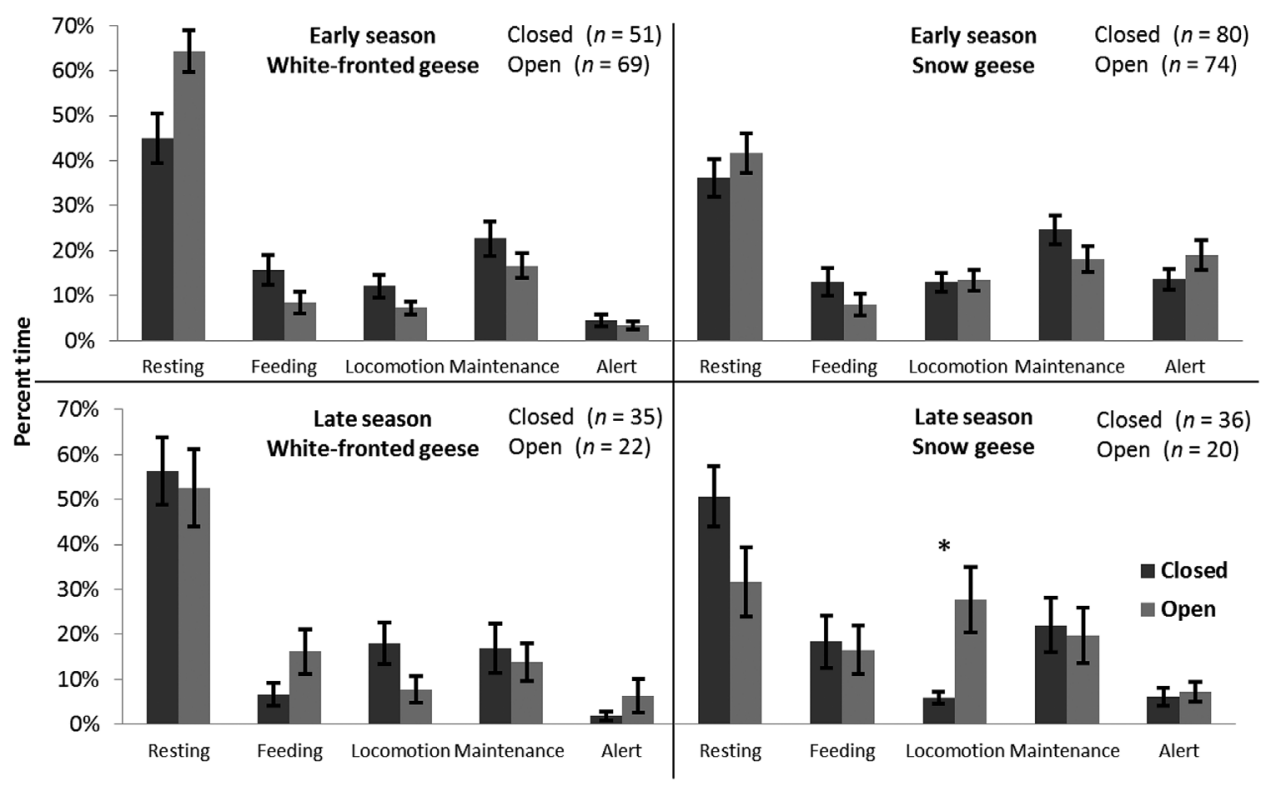

Figure 4. Percent time $(\bar{x} \pm \mathrm{SE})$ spent by greater white-fronted geese and lesser snow geese in behaviors during early and late seasons on wetlands open and closed to hunting during the Light Goose Conservation Order in the Rainwater Basin (RWB) of Nebraska, USA, during 2011 and 2012 . We classified early season as those weeks prior to the date when $>95 \%$ of all light geese observed on study wetlands each year had left the RWB region, late season was considered all weeks after that date. The social behavior for geese was recorded rarely and is excluded from figure. The asterisk symbol indicates statistical differences $(P \leq 0.05)$ between categories. 


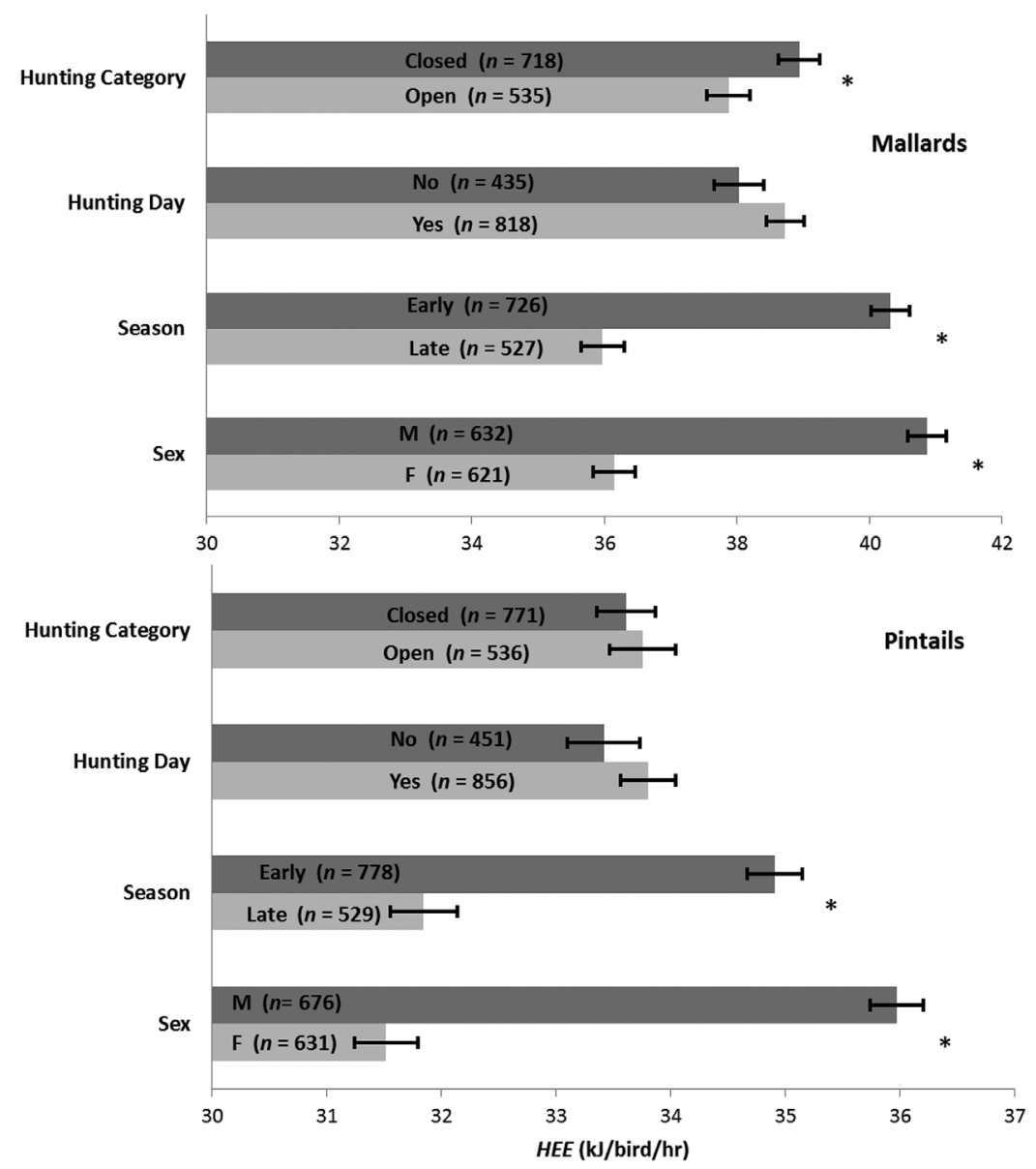

Figure 5. Mean $( \pm \mathrm{SE})$ hourly energy expenditure (HEE; $\mathrm{kJ} / \mathrm{bird} / \mathrm{hr})$ of mallards (Anas platyrhynchos) and northern pintails (A. acuta) for independent variables of hunting category, hunting day, season, and sex on study wetlands during the Light Goose Conservation Order in the Rainwater Basin of Nebraska, USA, during spring 2011 and 2012. The asterisk symbol indicates statistical differences $(P \leq 0.05)$ between categories.

likely to be influenced by hunting disturbance than target species and our results support these findings. However, our sample sizes for behavioral observations of both white-fronts and snow geese were relatively low compared with dabbling duck sample size. Diets of snow geese and white-fronts staging in the RWB consist of $>95 \%$ corn (Pearse et al. 2013); thus, differences in behavior, especially foraging rates, for geese would likely not be affected by hunting disturbance on RWB wetlands. Although overall snow goose behavior did not differ between hunting categories, snow geese spent considerably more time in alert behavior on both wetlands open and closed to hunting than did white-fronts, which was likely the result of continual hunting pressure during autumn, winter and spring migration. Increased time in alert activities potentially reduced foraging time for snow geese, but these effects could be considered a collateral benefit in the effort to reduce midcontinent light goose populations (USFWS 2007).

Several studies have related the effects of anthropogenic activities to energy expenditure in waterbirds (Belanger and Bedard 1990, Schummer and Eddleman 2003, Bechet et al. 2004, Klaassen et al. 2006). In our study, we found no difference in energy expenditure for pintails between wetlands open and closed to hunting. Mallards had greater energy expenditure (although small and perhaps inconsequential) on wetlands closed to hunting, compared with wetlands open to hunting; therefore, we could not attribute greater energy expenditure to hunting disturbance. Schummer and Eddleman (2003) also reported no differences in energy expenditure for American coots (Fulica americana) between undisturbed and disturbed periods. However, several studies reported greater energy expenditure from hunting disturbance as the result of increased flight time (Belanger and Bedard 1990, Bechet et al. 2004, Jones et al. 2014). Our energy models did not account for energy expended during flight, which is the most energetically expensive $(12.5 \times$ Resting Metabolic Rate) behavior, based on estimates derived by Wooley (1976). Flight time is often difficult to account for and frequently underestimated in time activity budgets (Paulus 1988). Accounting for energy expended during flight increased daytime energy expenditure estimates for mallards (Jorde et al. 1984) and American black ducks (A. rubripes; Jones et al. 2014). We speculate inclusion of flight activity during behavior observations in our study would have resulted in greater HEE estimates and perhaps made potential differences in energy expenditure on wetlands open and closed to hunting easier to detect. 


\section{MANAGEMENT IMPLICATIONS}

Foraging time for dabbling ducks may be reduced on wetlands open to hunting during the LGCO in some years (this study, Webb et al. 2011). Consequently, providing disturbance-free wetlands that offer foraging opportunities on important macroinvertebrates and natural plant seeds for dabbling ducks is likely an important management strategy in the RWB (Tidwell et al. 2013). However, we found no effects of hunt day in our analyses of dabbling duck behaviors or HEE, as well as no effects of LGCO activities on the behaviors of white-fronts. Given these results, if the current network of closed wetlands remains, a LGCO season with increased allotted hunting time (i.e., open 7 days/week) will likely have minimal additional effects on the behaviors or energy expenditure of nontarget waterfowl species that are using the region for spring staging. Providing more hunting time may also increase hunter participation and ultimately aid in the reduction of midcontinent light goose populations.

\section{ACKNOWLEDGMENTS}

We would like to thank the Nebraska Game and Parks Commission, the U.S. Geological Survey Missouri Cooperative Fish and Wildlife Research Unit and the E. K. Love Fellowship for providing funding and logistical support for this project. Additional logistical support was provided by the Rainwater Basin Joint Venture and Rainwater Basin Wetland Management District. We gratefully acknowledge H. Johnson and E. Teter for their assistance collecting field data and J. Fontaine and for helpful comments on earlier versions of the manuscript. We especially would like to thank Associate Editor A. Pearse and all other reviewers that have helped improve this manuscript. The Missouri Cooperative Fish and Wildlife Research Unit is jointly sponsored by the Missouri Department of Conservation, the University of Missouri, the U.S. Fish and Wildlife Service, the U.S. Geological Survey, and the Wildlife Management Institute. Any use of trade, firm, or product names is for descriptive purposes only and does not imply endorsement by the U.S. Government.

\section{LITERATURE CITED}

Abraham, K. F., and R. L. Jefferies. 1997. High goose populations: causes, impacts and implications. Pages 7-72 in B. D. J. Batt, editor. Arctic ecosystems in peril: report of the Arctic Goose Habitat Working Group. Arctic Goose Joint Venture Special Publication. U.S. Fish and Wildlife Service, Washington, D.C., USA; and Canadian Wildlife Service, Ottawa, Ontario, Canada.

Abraham, K. F., R. L. Jefferies, and R. T. Alisauskas. 2005. The dynamics of landscape change and snow geese in mid-continent North America. Global Change Biology 11:841-855.

Albright, J. J. 1983. The effects of winter weather on the behavior and energy reserves of black ducks in Maine. Transactions of the Northeast Section of the Wildlife Society 40:118-128.

Alisauskas, R. T., R. F. Rockwell, K. W. Dufour, E. G. Cooch, G. Zimmerman, K. L. Drake, J. O. Leafloor, T. J. Moser, and E. T. Reed. 2011. Harvest, survival, and abundance of midcontinent lesser snow geese relative to population reduction efforts. Wildlife Monographs 179 .

Altman, J. 1974. Observational study of behavior: sampling methods. Behavior 49:227-267.

Anteau, M. J., and A. D. Afton. 2004. Nutrient reserves of lesser scaup (Aythya affinis) during spring migration in the Mississippi Flyway: a test of the spring condition hypothesis. Auk 121:917-929.
Arzel, C., J. Elmberg, and M. Guillemain. 2006. Ecology of springmigrating Anatidae: a review. Journal of Ornithology 147:167-184.

Baldassarre, G. A., and E. G. Bolen. 1984. Field-feeding ecology of waterfowl wintering on the Southern High Plains of Texas. Journal of Wildlife Management 48:63-71.

Baldassarre, G. A., R. J. Whyte, E. E. Quinlan, and E. G. Bolen. 1983. Dynamics and quality of waste corn available to postbreeding waterfowl in Texas. Wildlife Society Bulletin 11:25-31.

Bechet, A., J. F. Giroux, and G. Gauthier. 2004. The effects of disturbance on behavior, habitat use and energy of spring staging geese. Journal of Applied Ecology 41:689-700.

Belanger, L., and J. Bedard. 1989. Responses of staging greater snow geese to human disturbance. Journal of Wildlife Management 53:713-719.

Belanger, L., and J. Bedard. 1990. Energetic cost of man-induced disturbance to staging snow geese. Journal of Wildlife Management 54:36-41.

Bishop, A. A., and M. Vrtiska. 2008. Effects of the Wetlands Reserve Program on waterfowl carrying capacity in the Rainwater Basin Region of south-central Nebraska. Natural Resource Conservation Service, U.S. Department of Agriculture, Grand Island, Nebraska, USA.

Brennan, E. K., L. M. Smith, D. A. Haukos, and T. G. LaGrange. 2005. Short-term response of wetland birds to prescribed burning in Rainwater Basin wetlands. Wetlands 25:667-674.

Clark, R. G., J. P. Fleskes, K. L. Guyn, D. A. Haukos, J. E. Austin, and M. R. Miller. 2014. Northern pintail (Anas acuta). Account 163 in P. G. Rodewald, editor. The birds of North America. Cornell Lab of Ornithology, Ithaca, New York, USA. DOI: 10.2173/bna.163. https:// birdsna.org/Species-Account/bna/species/norpin. Accessed 29 Sep 2015.

Cowardin, L. M., V. Carter, F. C. Golet, and E. T. Laroe. 1979. Classification of wetlands and deepwater habitats of the United States. Second edition. U.S. Fish and Wildlife Service Report FGDC-STD-0042013, Washington, D.C., USA.

Davis, C. A., and L. M. Smith. 1998. Behavior of migrant shorebirds in playas of the Southern High Plains, Texas. Condor 100:266-276.

Devries, J. H., R. W. Brook, D. W. Howerter, and M. G. Anderson. 2008. Effects of spring body condition and age on reproduction in mallards (Anas platyrhynchos). Auk 125:618-628.

Dinges, A. 2013. Participation in the Light Goose Conservation Order and effects on behavior and distribution of waterfowl in the Rainwater Basin of Nebraska. Thesis, University of Missouri, Columbia, USA.

Dinges, A. J., E. B. Webb, and M. P. Vrtiska. 2015. Effects of the Light Goose Conservation Order on non-target waterfowl distribution during spring migration. Wildlife Biology 21:88-97.

Drent, R. H., G. Eichhorn, A. Flagstad, A. J. Van der Graaf, K. E. Litvin, and J. Stahl. 2007. Migratory connectivity in Arctic geese: spring stopovers are the weak links in meeting targets for breeding. Journal of Ornithology 148:501-514.

Drent, R. H., A. D. Fox, and J. Stahl. 2006. Travelling to breed. Journal of Ornithology 147:122-134.

Drilling, N., R. Titman, and F. McKinney. 2002. Mallard (Anas platyrhynchos). Account 658 in A. Poole, editor. The birds of North America online. Cornell Lab of Ornithology, Ithaca, New York, USA. DOI: 10.2173/bna.658. https://birdsna.org/Species Account/bna/species/ mallar. Accessed 29 Sep 2015.

Finch, H. 2005. Comparison of the performance of nonparametric and parametric MANOVA test statistics when assumptions are violated. Methodology: European Journal of Research Methods for the Behavioral and Social Sciences 1:27-38.

Gersib, R. A., B. Elder, K. F. Dinan, and T. H. Hupf. 1989. Waterfowl values by wetland type within Rainwater Basin wetlands with special emphasis on activity time budget and census data. Nebraska Game and Parks Commission and U.S. Fish and Wildlife Service. Lincoln, USA.

Gordon, C. C., L. D. Flake, and K. F. Higgins. 1990. Aquatic invertebrates in the Rainwater Basin area of Nebraska. Prairie Naturalist 22:191-200.

Greer, D. M., B. D. Dugger, K. J. Reinecke, and M. J. Petrie. 2009. Depletion of rice as food of waterfowl wintering in the Mississippi Alluvial Valley. Journal of Wildlife Management 73:1125-1133.

Heitmeyer, M. E. 1985. Wintering strategies of female mallards related to dynamics of lowland hardwood wetlands in the Upper Mississippi Delta. Dissertation, University of Missouri, Columbia, USA.

Jefferies, R. L., and R. F. Rockwell. 2002. Foraging geese, vegetation loss and soil degradation in an Arctic salt marsh. Applied Vegetation Science 5:7-16. 
Jones, O. E., C. K. Williams, and P. M. Castelli. 2014. A 24 hour timeenergy budget for wintering American black ducks (Anas rubripes) and its comparison to allometric estimations. Waterbirds 37:264-273.

Jorde, D. G., G. L. Krapu, D. C. Crawford, and M. A. Hay. 1984. Effects of weather on habitat selection and behavior of mallards wintering in Nebraska. Condor 86:258-265.

Kendeigh, S. C., V. R. Dol'nik, and V. M. Gavrilov. 1977. Avian energetics. Pages 127-204 in J. Pinowski and S. C. Kendeigh, editors. Granivorous birds in ecosystems: their evolution, populations, energetics, adaptations, impact, and control. Cambridge University Press, New York, New York, USA.

Klaassen, M., S. Bauer, J. Madsen, and I. Tombre. 2006. Modelling behavioural and fitness consequences of disturbance for geese along their spring flyway. Journal of Applied Ecology 43:92-100.

Krapu, G. L., K. J. Reinecke, and D. G. Jorde. 1995. Spring staging ecology of mid-continent greater white-fronted geese. Journal of Wildlife Management 59:736-746.

LaGrange, T. G. 2005. Guide to Nebraska's wetlands and their conservation needs. Nebraska Game and Parks Commission, Lincoln, USA.

Loesch, C. R., and R. M. Kaminski. 1989. Winter body-weight patterns of female mallards fed agricultural seeds. Journal of Wildlife Management 53:1081-1087.

Madsen, J., and A. D. Fox. 1995. Impacts of hunting disturbance on waterbirds—a review. Wildlife Biology 1:193-207.

Mainguy, J., J. Bety, G. Gauthier, and J. F. Giroux. 2002. Are body condition and reproductive effort of laying greater snow geese affected by the spring hunt? Condor 104:156-161.

McKinney, R. A., and S. R. McWilliams. 2005. A new model to estimate daily energy expenditure for wintering waterfowl. Wilson Bulletin 117: 44-55.

Miller, M. R. 1987. Fall and winter foods of northern pintails in the Sacramento Valley, California. Journal of Wildlife Management 51: 405-414.

Miller, M. R., and J. McA. Eadie. 2006. The allometric relationship between resting metabolic rate and body mass in wild wintering waterfowl (Anatidae) and an application to estimation of winter habitat requirements. Condor 108:166-177.

Paulus, S. L. 1982. Feeding ecology of gadwalls in Louisiana in winter. Journal of Wildlife Management 46:71-79.

Paulus, S. L. 1988. Time-activity budgets of nonbreeding Anatidae: a review. Pages 135-152 in M. W. Weller, editor. Waterfowl in winter. University of Minnesota Press, Minneapolis, USA.

Pearse, A. T., G. L. Krapu, and R. R. Cox, Jr. 2012. Spring snow goose hunting influences body composition of waterfowl staging in Nebraska. Journal of Wildlife Management 76:1393-1400.

Pearse, A. T., G. L. Krapu, and R. R. Cox, Jr. 2013. Comparative springstaging ecology of sympatric Arctic-nesting geese in south-central Nebraska. American Midland Naturalist. 169:371-381.

Pearse, A. T., G. L. Krapu, R. R. Cox, Jr., and B. E. Davis. 2011. Spring migration ecology of northern pintails in south-central Nebraska. Waterbirds 34:10-18.
Reinecke, K. J., R. M. Kaminski, D. J. Moorehead., J. D. Hodges, and J. R. Nassar. 1989. Mississippi Alluvial Valley. Pages 203-247 in L. M. Smith, R. L. Pederson, and R. M. Kaminski, editors. Habitat management for migrating and wintering waterfowl in North America. Texas Tech University Press, Lubbock, USA.

Rümmler, M. C., O. Mustafa, J. Maercker, H. U. Peter, and J. Esefeld. 2016. Measuring the influence of unmanned aerial vehicles on Adélie penguins. Polar Biology 39:1329.

SAS Institute Inc. 2010. SAS/STAT user's guide. SAS Institute, Cary, North Carolina, USA.

Schummer, M. L., and W. R. Eddleman. 2003. Effects of disturbance on activity and energy budgets of migrating waterbirds in south-central Oklahoma. Journal of Wildlife Management 67:789-795.

Smith, B. J., and K. F. Higgins. 1990. Avian cholera and temporal changes in wetland numbers and densities in Nebraska's Rainwater Basin area. Wetlands 10:1-5

Smith, B. J., K. F. Higgins, and C. F. Gritzner. 1989. Land use relationships to avian cholera outbreaks in the Nebraska Rainwater Basin Area. Prairie Naturalist 21:125-136.

Stewart, R. E., and H. A. Kantrud. 1971. Classification of natural ponds and lakes in the glaciated prairie region. Bureau of Sport Fisheries and Wildlife Resource Publication 92. U. S. Fish and Wildlife Service, Washington, D. C., USA.

Tidwell, P. R., E. B. Webb, M. P. Vrtiska, and A. A. Bishop. 2013. Diet and food selection of female mallards and blue-winged teal during spring migration. Journal of Fish and Wildlife Management 4:63-74.

U.S. Fish and Wildlife Service [USFWS]. 2007. Final Environmental Impact Statement: Light Goose Management. Washington, D.C., USA.

U.S. Fish and Wildlife Service [USFWS] and Canadian Wildlife Service. 1986. North American waterfowl management plan. U.S. Fish and Wildlife Service, Washington, D.C., USA.

Vrtiska, M. P., and S. Sullivan. 2009. Abundance and distribution of lesser snow and Ross's geese in the Rainwater Basin and central Platte River Valley of Nebraska. Great Plains Research 19:147-155.

Webb, E. B., L. M. Smith, M. P. Vrtiska, and T. G. LaGrange. 2010. Effects of local and landscape variables on wetland bird habitat use during migration through the Rainwater Basin. Journal of Wildlife Management 74:109-119.

Webb, E. B., L. M. Smith, M. P. Vrtiska, and T. G. LaGrange. 2011. Factors influencing behavior of wetland birds in the Rainwater Basin during spring migration. Waterbirds 34:457-467.

Wooley Jr., J. B. 1976. Energy expenditure of the black duck under controlled and free-living conditions. Thesis, University of Maine, Orono, USA.

Wooley Jr., J. B., and R. B. Owen. 1977. Metabolic rates and heart ratemetabolism relationships in the black duck (Anas rubripes). Journal of Comparative Biochemistry and Physiology 57:363-367.

Zar, J. H. 1999. Biostatistical analysis. Prentice Hall, Upper Saddle River, New Jersey, USA.

Associate Editor: Pearse. 